\title{
Javanese and the Samin Community: A Reflection of Ideology and Identity of Its Speakers
}

\author{
Suhandano \\ Faculty of Cultural Sciences, Universitas Gadjah Mada, Indonesia \\ Email: suhandano@ugm.ac.id
}

\begin{abstract}
Javanese has several variants, one of which is the Javanese spoken by the Samin community, a group of Javanese people who uphold Saminist teachings. This paper discusses the Javanese of the Samin people within the framework of anthropological linguistics, a study of languages in a cultural and social context. The paper addresses two questions: what are the characteristics of the Javanese spoken by the Samin people and why does their Javanese language have such these characteristics. Based on data gathered during extensive fieldwork, it was found that there are at least three characteristics of the Samin community's Javanese: (i) Samin people tend to speak Javanese at the ngoko level; (ii) they use several specific words/lexicons; and (iii) different attitudes are shown in spoken communication. It seems that these three characteristics are related to their world view, ideology and identity. The Samin people, for example, consider that all people have the same status so there is no need to make these differentiations when speaking. That's why they tend to speak Javanese at the ngoko level and address others by the same word sedulur, meaning relatives. Likewise, their attitude in speaking, such as leaving a conversation before it becomes a quarrel, reflects their view that a quarrel tends to hurt others so must be avoided. These findings reinforce the view that language is closely related to the speaker's world view that is, their ideology and identity. The relationship of ideology, language and identity, in the case of the Samin people, seems to be a linear progression. Their ideology influences their language, and then, their language constructs their identity. The study of language in the socio-cultural context of the speakers not only provides a better understanding of the language but also a better understanding of the characteristics of the speakers.
\end{abstract}

Keywords: identity; ideology; Javanese; Samin people; world view

\section{INTRODUCTION}

Samin people (wong Samin in Javanese) is the term used to refer to a group of people in Javanese society who uphold Saminist teachings. Wong Samin usually is used by outsiders, but for Samin people they call themselves sedulur sikep (literally, relatives with a way of thinking). In general, Samin people live in groups (communities), spread over several places in the north-eastern parts of Central Java Province, such as in the regencies of Pati, Rembang, and Blora. Some Samin people also inhabit several other places in East Java Province. In general, Samin people live in certain residential areas which consist of several houses (householders). However, the residential borders between Samin and non-Samin people are not always clearly defined. There are also several Samin people who do not live communally, but live among non-Samin people. These people think of themselves as a part of the surrounding society, rather than being part of an exclusive group.

At first glance, Samin people appear to be no different to other Javanese people. But by careful observation, certain characteristics emerge which are different to the general Javanese population. These differences are reflected in, among others, their way of living, for instance Samin people working exclusively as 
farmers from dawn til dusk, rejecting other occupations This preference manifests itself in their beliefs about the world and, as Stryker (1980) notes, then forms an identity. The manifestation of Samin beliefs is also found in their way of speaking. When asked one's age, people will generally answer by stating a number of years, such as twenty. Samin people, however, tend to answer such question by saying umurku siji 'my age is one'. This answer does not mean that they are literally one years old rather it is perception of life which is "umur ya mung siji, dienggo sak lawase" 'age is only one, and is used for an age'.

There are other anomalies in their language variety. Generally, there are speech levels used in Javanese society applicable to the rank or social class of the interlocuters; ngoko (low Javanese), madya (middle Javanese), krama (refined Javanese), and "respect vocabularies" (Poedjosoedarmo, 1968; and Errington, 1982). The differences among these levels, the rationales for choosing one or another, are conceived by users in terms of ideas about affectivity and social hierarchy. Wolff and Poedjosoedarmo (1982) state that krama, is considered to be depersonalized, flat-affect, and regulated by an ethic of proper order, peace, and calm. The lower, "coarser" levels called ngoko. Regardless of this common language, Samin people tend to use ngoko to address other speakers. For instance, in a proposing marriage, a Samin young man asks, in ngoko not krama, to his possible parents-in-law for their daughter's hand. These characteristics of the Samin people's language possibly leads to misunderstanding for outsiders and to consider them as strange. Outsiders have created the utterance "dasar Samin!" intended as criticism for characteristic Sarmin behaviours

This paper describes the variant of Javanese spoken by Samin people and discusses it in the framework of anthropological linguistics, a sub-field of linguistics which is concerned with the place of language in its wider cultural and social context (Foley, 2001). The paper focuses on the interwoven nature of language, ideology and the identity of its speakers. It addresses two questions: (i) what are the characteristics of the Javanese variant spoken by the Samin people, and (ii) what are the reasons for the use of this variant. The answers to these questions will provide an understanding of the reasons for the existance of language variants. The language phenomenon of the Samin people shows that the Javanese variant they speak reflects their world view, ideology and identity. The Javanese of Samin people is not a geographical variant of Javanese, it is an ideological variant of the language. In addition, this paper seeks to dispel negative assumption about Samin people and promote understanding.

This paper seeks to discuss this language variant more comprehensively than existing studies which generally focus on a particular language aspects of the Samin people's Javanese. Suhandano (2015) for example, discusses the lexicon in this language variant. He found that specific words in the Javanese of Samin people reflects the world view of its speakers which is influenced by the ideology of Saminism. Meanwhile, Fatmawati (2017) discusses the uniqueness of the Javanese of Samin people from the aspect of the principles of cooperation in communication. In speaking, the Samin people violate these principles so that it causes misunderstanding to others.

As Dunmore (2019:17) states, over the past fifty years researchers have established that the interplay of language, culture and society is both complex and context-specific. Field (2012) who studied Kumeyaay language variation, a language spoken at the southern border of California in the United States and the northern border of Baja California in Mexico, argues that an understanding of the connection between language, group identity, historical differences in socio-political organization and access to environmental resources of its speakers are important variables to explain the nature of dialect variation across Kumeyaay communities in Alta and Baja California, which is largely lexical. The Arabic language is also considered unique in portraying language identity. In Yemen, which shares the same dialect, there is the anomaly of the Yemeny language variety of Jabal Razih which has different linguistics features. Watson, et al. (2006) examined that differences in linguistic features are influenced by ancient South Arabian language in the early centuries AD. This language was maintained by Yemeni speakers as a symbol of political and social identity. This diversity is questioned whether Yemeni is a new language or the same dialect influenced by an ancient language.

In linguistic studies language can be related to the ideology, identity and world view of its speakers. In what is known as the Sapir-Whorf hypothesis (Sampson, 1980) it is stated that language reflects the world view of its speakers. And, according to Wierzbicka (1992) language doesn't reflect the world directly, it reflects human conceptualization, human interpretation of the world. How people perceive the world is influenced by their ideology. The term 'ideology' usually refers to beliefs, myths and doctrines held by different social groups and the manner in which they are contested by those groups in society. There are many definitions of language 
ideology, from wide-ranging beliefs or feelings about languages to the more precise cultural systems of ideas about social and linguistic relationships, together with their loading of moral and political interests (Dunmore, 2019). Irvine (1998) points out that language ideology is the representation of the linkages between "language, social rank, respect and appropriate conduct".

The meaning of "language" in language and ideology talks has a wide range of meanings, not only referring to particular languages such as Javanese, Indonesian and English, but also referring to variants in the language. Of note is that language ideology and its variant happens in the same speech community. As defined by Chambers, Trudgill \& Scheeling-Estes (2003: 267), a speech community cannot be simply defined as people who speak the same language, but rather communal linguistic variations which shares similar norms and complex values. To give an example, Irvine (1998) states that the language of Javanese is a reflection of the complexity and subtlety of a sociolinguistics system leading to Javanese society's social ideology. In the case of Javanese language, Irvine points out that language identity is not expressed individually but as a norm in which one does not express his/her feelings because Javanese language is addressee-focused. This condition is also replicated in the Javanese of the Samin people.

Identity can be broadly defined as a person's sense of belonging to, or alignment with, a specific social group, society or place where language is generally assumed to be one of the most salient markers of identity (Carlin, Eithne B. et al., 2015: 3). Dunmore (2019:19) states that the study of the relationship between language and identity is complex and continues to spark debate. He reiterates Joseph's (2004) statement that language and identity are ultimately inseparable, since language is central to the human condition. Chakraborty (2018) says that language expresses and constructs identities. And, as Lian (2020) says, language does more than merely refer to the external world and convey ideas from the mind. It is also indexical, as formal and stylistic variations in language use index social differences: settings, topics, positions, institutions and, ultimately, identities language users. The discussion in this paper is based on the view that language does not perceive self-identity but group identity (Hansen \& Liu, 1997; Tagliamonte, S. A., 2006). Woolard and Schieffelin (1994) assert that language reflects political, social and moral worth in a society. So, different language ideology creates variation in language use which represents a group's identity.

This paper is a result of almost a year of fieldwork in several Samin villages in Pati, Rembang and Blora districts. Data collection was carried out by observation and interviews in the three districts. Researchers, assisted by research assistants, recorded data from several speech events in the Samin community. The data records were then transcribed into data cards for further identification and analysis. Data identification includes identification of language codes, characteristics of linguistic units, participants in speech events, speech situations, and other information that are considered relevant. The analysis was carried out by interpreting the results of identification data, looking at the relationship among identification units, and interpreting them in relation to the sociocultural aspects of the Samin community. To gain more detailed information and to confirm and verify the results of the analysis, the researcher conducted interviews with a number of Samin figures.

\section{FINDINGS AND DISCUSSION Speech Codes in Samin Community}

As mentioned previously, Samin people do not think of themselves as different to those in their surrounding areas. In daily life, they interact not only with Samin people, but also with people outside their group. Therefore, the speech codes they use are not significantly different from the ones used in the surrounding society. There are three types of speech codes among Samin people, that is, the Javanese ngoko and krama levels and Indonesian. The mastery of these three speech code types varies from one person to another. Some Samin people only master one type of speech code, some master two types, and some master all of them. It seems that the mastery of the number of speech codes is related to their age and life experience. Samin elders generally master only one type of speech code, the Javanese ngoko level, so do Samin children. Samin teenagers and adults however, master two or three types of speech codes.

An important Samin community figure said that Samin people used to speak only one type of speech code, ngoko. They used this code for both formal and informal speech situations. Samin people also speak ngoko when talking to respected figures, people with higher social status, older people, and strangers in contrast to other Javanese speakers who use krama in such speech situations.

The use of ngoko for all speech situations by Samin people had caused a perception of Samin people as being impolite. However, over time, communication between Samin people and outsiders has become more intensive. In fact, they too now feel uncomfortable when 
communicating with outsiders in ngoko as it can cause this negative perception. They will adopt the speech code to conform with the norms of the general Javanese speaker using krama to show respect. Samin teenagers and adults now also master krama although its use is still limited, mainly for communicating with the outsiders As Mardikantoro (2012a) states, there has been a shift in the language of the Samin community. Mardikantoro (2012b) reports that krama has also used in the family domain. This did not happen in the past and even now only occur in a few families. Based on this writer's field observations, in general, Samin people still not only use the ngoko level when talking to family members but also with guests in their home. As part of this research, I visited several houses and the Samin family members used the ngoko level with me.

Apart from the ngoko and krama speech codes, there is another in the Samin community, Indonesian, the main language in Indonesia. As a part of Indonesian society, the Samin community cannot avoid using this code. Those who master Indonesian are generally teenagers and adults. For adults, in general they have a passive command of Indonesian only. Some of them can understand for example radio and television broadcasts in Indonesian but they have difficulty when they try to recount this in Indonesian.

Most Samin children can also speak Indonesian. They learn Indonesian at school, and through watching television and listening to the radio. As Indonesian is the medium of instruction at school, it means Samin children will gain a mastery of this speech code. However, it should be noted that not all Samin children go to school. Even now there are several Samin parents who are not willing to send their children to school. They believe that educating the children is the parent's duty hence do not need to send their children to school unless they are unable to educate them. An informant explained this situation based on his definition of the word school. According to him, the word school, in Javanese sekolah, comes from the Javanese phrase seseking polah which means out-of-control behaviour. This means that parent will send their children to school when they are no longer able (sesak) to direct their children's behaviour (polah). If they are still able, they do not need to send their children to school. Even if Samin parents send their children to school, these children in general do not complete their schooling. When their children are able to read, write, and do arithmetic, the parents will take their children out of school. They believe this knowledge is sufficient to live their lives, as certificates are not needed to do not needed to work as a farmer.
The change in the Samin people's attitude to educating their children at school began in the last twenty years. In the past, they were not willing to send their children to school at all. Therefore, Samin people who are 30 years old or above generally did no schooling. For children and teenagers school is where they learn Indonesian, in contrast some Samin adults learn it from mass media such as television and radio, as well as from social intercourse. Social intercourse also becomes a way of learning Indonesian. However, not all Samin people are exposed to a wide range of social intercourse. Some of them rarely travel very far. One informant said that, during his 70 years of life, he had never been to the district capital which was only around thirty kilometers away from his home. Samin people generally prefer to spend their time to work in the rice fields which are located near their houses. However, there are also some Samin people who often visit distant places and have a wide range of social intercourse. For these people, mastering Indonesian is unavoidable since the language is the main language in Indonesia.

These types of speech codes in Samin society are not different to those found in Javanese society: ngoko, krama level and Indonesian. The uses of these three codes, however, are different. In traditional ceremonies, such as a wedding ceremony, krama is commonly in general Javanese society, while ngoko variety is used in Samin society. When talking in public, in Javanese society either krama or Indonesian is used, while in the Samin community there is a tendency to use ngoko.

The differences in the use of the speech codes in the Samin community compared to Javanese society are caused by some underlying factors. For Samin people, ngoko is considered to be appropriate to meet their communication needs. Therefore, they use this code in almost all aspects of life and in almost all speech situations. The use of ngoko variety can reflect their ideology based on internalized Saminist teachings. From the perspective of Samin ideology, all people are equal and must be respected. They believe that sak elek-eleke manungsa mesthi ana apike, lan sak apik-apike manungsa mesthi ana eleke (no matter how bad a person is, he must have a good side and no matter how good a person is, he must also have a bad side). Generally, Samin people consider other people as good, and do not have a prejudice against them. They also consider them as brothers, as reflected in the lexicon sedulur 'relatives' used to address other people. Javanese people in general, use it to refer to people with whom they have kinship ties although there is also a tendency to use it as the Samin community does. This is particularly evident when Javanese interact in 
writing on social media. As a consequence of Saminist beliefs that all people are basically good and all people must be respected, Samin people believe there is no need to differentiate speech codes, hence speaking in ngoko is appropriate.

Samin people regard ngoko above the other types of speech codes. In fact, for some of Samin people, there is an attitude of only using this variety of Javanese. When talking to non-Samin Javanese, for instance, some of them keep using ngoko even if their interlocutors speak krama. There is an unwillingness to change their speech code to suit their interlocutors and remain unworried if other people consider them impolite. An informant also shared a story that at a meeting, a member of the Samin community was asked to speak in front of the public which included non-Samin people. The speakers in that meeting were important figures in the society and they all spoke in krama. However, when a member of the Samin community took his turn to speak, he confidently spoke in ngoko.

The research shows that there is a strongly held attitude in Samin people in regarding ngoko as being above other speech codes. This seems to be related to their wish to speak the way their ancestors did, or as mentioned previously, a consequence of the Saminist teaching which has been passed down. However, not all members of Samin society act that way in always using ngoko. There are some members who are willing to adjust their speech codes to suit their interlocutors. When their interlocutors speak krama, some of the informants of this research responded in krama while others in ngoko. This might be related to their relative obedience in upholding the Saminist teaching. Conservative Samin people tend to have a more deeply held attitude in using ngoko, while moderate ones less so.

Samin people's attitude to krama is similar to that Indonesian however, they are even less inclined to use Indonesian. An informant stated the Samin belief that wong Jawa ki omonge ya nganggo basa Jawa (Javanese should speak Javanese). Such statement shows that Javanese is regarded as the first language for Samin people so that they will not choose to use Indonesian, unless the situation is unavoidable. When the interlocutor speaks Indonesian, they usually will not respond in Indonesian, but in Javanese. Nevertheless, there are a few Samins who are willing to respond in Indonesian; this usually happens to Samin teenagers. In this study, for example, the researcher once sent a message in writing in Indonesian via a mobile phone to several Samin people. When messages are sent to teenagers, they generally respond in Indonesian. However, when messages are sent to adults, they do not respond in writing but instead they call a speak in in ngoko. The data gather shows a generational difference between Samin teenagers and adults towards using Indonesian.

Unlike Javanese society in general, Samin people do not consider Indonesian as an important part of their communication and are unwilling to use this language. Even for Samin people who are fluent in Indonesian, they will not always respond to their interlocutors in Indonesian. When they know that their interlocutors can speak Javanese, they prefer to respond in Javanese. In addition, even when they know that the interlocutors do not speak Javanese, they still prefer to speak Javanese as long as there is someone who can translate what they say into the interlocutors' language. One such case was an informal speech situation which involved Samin and non-Samin people. One of the non-Samin people, who did not speak Javanese, used Indonesian. However, his interlocuter, a member of the Samin community only used Javanese in response so that his utterances had to be translated into Indonesian by the other interlocutors.

The ngoko level is the dominant speech code in the Samin community. This seems to be related to their view that all people have the same position so there is no need for status to be distinguished when speaking. Using Javanese speech codes at the ngoko level does not mean that they do not respect others, nor being impolite. The using of Javanese speech codes is related to their ideology that Javanese people should speak Javanese. It is the language of Javanese that distinguishes Javanese from others. This perspective and ideology applies to all Samin people, despite being dispersed over several areas, remaining a part of their identity.

\section{Specific Lexicons}

Samin people are different from other Javanese people in speaking not only in the speech codes used but also in some lexicons used. Even though most of the lexicons they use are the same as the ones found in common Javanese, a number of lexicons are found to be different or to have different meanings. Words such as pondhokan, rukunan, salin sandhangan, sedulur, and turun are examples of typical words of the Samin people. These words are used in Samin communities in different regions, which are geographically far apart so that they cannot be considered as diffeences in geographical dialects. If these words were to be a geographical dialect of Javanese, the meanings of these words would be the same for the people who live around the Samin people and the Samin people meaning. The research however, shows this is not the case. Samin people's special words reflect the world view 
of the speakers (Suhandano, 2015). For example, while Javanese speakers generally use the word omah to mean house, the Samin people use the word pondhokan. The word pondhokan is a polymorphemic word, it consists of a stem pondhok which means temporary residence and the suffix -an. In the view of the Samin people, life in the world will not be forever, humans will only stay for a while or mondhok, after that life will change. That is why they use the word pondhokan. This word can remind them that they live in this world only mondhok, or the stay is temporary whereas the word omah, as commonly used by Javanese speakers, does not contain this meaning. The Samin people use the word rukunan for husband or wife, while other Javanese speakers use the word bojo. Like the word pondhokan, the word rukunan is also a polymorphic word, consisting of the stem rukun which means harmony and a suffix -an. According to Samin people, a husband and wife agree to live in harmony. A husband or wife is called rukunan. This word also reminds us that a husband and a wife must live in harmony. The word bojo, as commonly used by Javanese speakers, does not contain this meaning. For Samin people, words function not only to name something (as a label) but also to give information related to how something is viewed or thought of. In other words, lexicons become a way of viewing, thinking, and understanding something.

The use of the words turun 'descendant' and anak 'child' illustrates how the Samin community perceive their children. In the Samin community, a mother could say, "Bocah lanang kae anakku" which means 'That boy is my child'. However, if the sentence is spoken by a father, the sentence will be "Bocah lanang kae turunku". There are different words used by a mothers and father in referring to their child. A mother uses the word anak for her child, while a father uses the word turun. Why is there such a difference? A prominent figure in the Samin community said that a mother refers to her child as anak because it is the mother who gives birth or manak. (The word manak is a verb, formed from prefik $N$ - and stem anak). Fathers cannot call their children by the word anak because they do not give birth or manak, rather to make a descendant or nurunke. That is why fathers do not call their children by the word anak, but call them by the word turun. This accords with their philosophy that in speaking one should be honest, what is said should match the facts. Saminism teaches people to always tell the truth, not to lie, or speak according to the facts. In Angger-Angger Pangucap (Guidelines for Speaking) of the Samin people there is an expression putih putih, abang abang, which means that if it is white, say white and if it is red, say red (Mardikantoro, 2012a).
Another example which shows how the use of words for Samin people must portray the real situations or show honesty is in the use of the verb weneh 'to give'. When having a conversation with an informant about how knowledge is transferred to other people, the writer asked him Piye carane ilmu iku diwehke marang wong liya 'How is knowledge given to other people'. The informant revised my question by saying that Ilmu iku ora diwehke 'knowledge is not given'. When I asked further, why knowledge is not given, he explained that if knowledge is given, the one who gives the knowledge will lose his knowledge or the knowledge will decrease since it has been given to other people. Meanwhile, the fact is not so: the knowledge will not decrease even if it has been transferred to other people. According to this informant, the appropriate statement is Ilmu iku dikandhake marang wong liya 'knowledge is told to other people', not diwehke marang wong liya 'given to other people'.

The word nganggo 'to use' also contains an explanation. Samin people have their own concept of ownership. For Samin people, ownership of goods does not necessarily belong to an individual, but rather is held in communal ownership. For instance, Samins never think that they own water because water is a commodity which belongs to the community. Where Javanese requests water njaluk it implies a concept of individual ownership. A Samin person uses the lexicon nganggo 'to use' which is deemed more appropriate. Javanese in general are used to saying Aku arep njaluk banyumu 'I want to ask for your water' in seeking permission to use water that is in someone else's place, but the Samin people will not say that. Instead, they will say Aku arep nganggo banyune 'I want to use the water'. In the two sentences there are a number of differences. In addition to the different verbs used in the two sentences, njaluk 'to ask for' as opposed to nganggo 'to use', there are also differences in the forms of the nouns, a possessive noun banyumu 'your water' and a definite noun banyune 'the water'.

Because the word should reflect reality, Samin people also tend to interpret a concept based on the word that marks it, including words from foreign languages. How they interpret the word sholat provides a good illustration of this statement. As we know the word sholat in Javanese comes from Arabic. This word refers to the type of worship in Islam in the form of a series of ritual bowing and standing movements accompanied by ritual words of prayer five times a day. However, Samin people interpret this type of worship as an order to always speak honestly and properly. They arrive at that interpretation because the word sholat according to them is derived from the Javanese phrase solahing ilat 'movements of 
the tongue'; people should be careful in speaking, do not let what is said be untrue and hurt others. In other words, one should be careful in solahing ilat. This interpretation accords with the teachings of Saminism.

There are still many other specific words in the Samin people's Javanese. What can be concluded from these special words is that for the Samin people a word is not just a label of one thing to distinguish it from another thing, but more than that, a word should reflect actual reality.

\section{Attitudes to Speaking}

In addition to the use of speech codes and specific words, compared to Javanese speakers in general, the Samin people also show differences related to their attitudes when engaged in speaking. These differences can sometimes cause misunderstandings, especially for outsiders who do not understand these behaviours and would view the Samin people as impolite. For example, when involved in a conversation, the Samin people may abruptly leave the conversation without saying anything. When asked by people they don't know or by strangers, Samin people sometimes do not want to answer questions and even leave the questioners. In answering questions, Samin people may sometimes give answers that are not expected by the questioner. When someone asks, Umurmu pira? 'how old are you?', for instance, they answer, Siji 'One', this does not mean that they are one year old. When asked about an opinion of others, sometimes the Samin people are unwilling to answer and suggest the questioner to ask directly the person in question.

Why do Samin people show such behavours in speaking? The behaviour stems from certain views or ideologies shown in certain interactions. When Samin people suddenly leave a conversation without saying anything, it occurs when the conversation reaches a point which is not good for the interlocutors. When conversations might lead to a quarrel among the interlocutors, for example, Samin people usually withdraw themselves from the conversation. They believe that when a quarrel happens, the interlocutors will tend to offend each other and such a situation must be avoided. In order to avoid this, it is better for them to withdraw from the conversation. Samin people also believe that ones should never hurt or offend the other with their words so that everyone must be careful when speaking. As discussed above, one should be able to maintain sholat which stands for solahing ilat (tongue movement). Samin people will actually not leave any conversation if the conversation runs the way it is supposed to go. They will leave it when they think think that there have been utterances which can offend other interlocutors.

The Samin people also hold to a principle that when responding to another person's question, they should provide correct information. If they do have the information requested, they should not speculate about it. For the Samin people, leaving the questioner is considered a better alternative than giving wrong information. That is why, when asked by people who they do not know well, they sometimes leave the questioner. In the past Samin people also had limited interaction with people in their group or those around them and were less accustomed to interacting. Some of them tended to avoid meeting people they did not know. However, nowadays the Samin people are more open than in the past, a consequence of greater social intercourse, so an attitude of avoiding strangers is very rare.

Another different speaking behaviour of the Samin people is shown when they answer certain questions. As mentioned earlier, when someone asks about their age, they tend to answer siji 'one'. In this case, there is a difference in understanding about the concept of age between the Samin people and other people in general. The Samin people think that age is only one - the entire life span. They say that umur iku siji dinggo saklawase 'age is one and will be used forever'. They believe that when passing away it does not end the life. Instead, passing away is only salin sandhangan 'to change clothes' so that age cannot be counted in time units of years, months, and days. Another example of an unexpected answer is when they are asked, pira sapimu? 'how many cows do you have?'. The Samin people will answer the question by saying one or two, even though the number of cows they have is more than one or two. Such answers are given because they interpret such questions based on gender. For Samin people, there are only two kinds of cows, male and female cows, so that no matter how many cows they have, they must consist of only two types of cows, male and female. Another unexpected answer was also given by the Samin people when they are asked, Apa gaweanmu? 'What is your occupation?'. Samin adult men will say rabi meaning to wed and women will say laki which means having sexual intercourse. The word gawean which for Javanese speakers in general means occupation is defined differently by the Samin people.

An unexpected response was also shown by the Samin people when they were asked to protect rice plants in the rice fields from any possible bird threats. The sentence used was Tunggokna pariku! 'Stay with my rice plants!'. In response to this direction, the Samin people will only stay at the rice fields, but will not prevent any birds from eating the rice. Samin people 
think that they are being told to stay with the rice plants, but not to prevent the birds from eating the rice. Such responses occur because they understand the command based on the literal meaning of the utterance. It seems that such understanding has to do with their ideology about speaking truthfully but for outsiders can lead to misunderstandings.

The following story provides another example of how typical Samin attitudes are shown in speaking. An informant said that one time he visited a house of the Samin people and brought gifts. He placed the gifts in the house. After several days he visited the house again and saw that the gifts he had brought were untouched, and still in the same place. The person asked the Samin host why the gifts were still in the same place. The Samin man answered that the gifts did not belong to him. The guest said that he had brought the gifts for him and had left them in the house for him. The Samin host said that he did not know that the gifts were for him because his guest did not say so. The story shows that speech in Samin community is part of an action. Certain actions such as giving are not enough but must be accompanied by speech. They say that wong Jawa ki jawabe which means for Javanese people it is important to say something, not just to do something when interacting with others.

Samin's attitudes shown in speaking, which is sometimes considered strange by others, does not happen accidently, but there are things behind it. It is their ideology that makes them behave in that ways. They view that a quarrel is not good and should be avoided so they withdraw from the conversation when it leads to that situation. Samin people always want to give correct information when asked about something. They don't want to guess about something they don't know; they don't want to lie. Therefore, they will prefer to avoid questions from people they do not know. Samin people also have a different understanding about a number of things. So when asked certain questions, they could give unexpected answers from the point of view of the questioner.

\section{The Relationship of Ideology, Language, and Identity in the Samin Community}

Ideology affects how people view the world and has an influence on their language. People although speaking the same language will produce different variants of the language if they have different ideologies. That is what can be seen in the Javanese speaking community who follow the Saminist ideology. As speakers of Javanese, their Javanese is still understood by other Javanese speakers, but their language shows a peculiarity that distinguishes it from Javanese in general. The teachings of Saminism are a reference for their followers in their conducts, including in speaking.

Saminsme teaches how people should conduct themselves. There are at least three teachings that greatly influence their language behaviour namely,: (a) all people have the same status, (b) people must speak in accordance with reality and be honest, and (c) do not offend others so that quarrels can be avoided (aja tukar padu). The three characteristics of their language, compared to Javanese in general, are related to these three teachings of Saminism. They tend to speak Javanese at the ngoko level because Saminism teaches that everyone has the same status so there is no need to differentiate status in speech. They use special vocabulary because the existing vocabulary does not reflect the actual situation or does not reflect honesty. They show certain speaking behaviours, for example leaving conversations that could lead to a quarrel, because Saminism teaches people not to offend others and avoid ensuing arguments. Saminism teaches that people must be "bener pangucape, becik tumindakke" which means to speak the truth and behave properly. A teaching which has influenced their language.

In the case of the Samin people, ideology has affected their language and not the other way around. Saminism was propagated by Samin Surosentika in the late nineteenth and early twentieth centuries (Benda and Lance Castles, 1969). Before Samin's teachings gained ground, their language was likely no different to the language of the people around them although there have been no reports of this. It seems that the followers of Samin have gradually developed a variant of Javanese that is suitable as an expression of their ideology so that the Javanese variant of the Samin people was formed. As Brustad (2017) said, language does not offer usage, but rather is constantly being constructed and reconstructed by its users. The Javanese variant of the Samin people is formed through a process in line with the process of internalizing the Samin teachings in its followers. This variant of Javanese, therefore, is dynamic, subject to change from time to time. Its prominent language characteristics then would get stronger if the followers of Samin are more rigorous in applying Saminist ideology. On the other hand, if the followers of Saminism pay less attention to the teachings of Saminism, it is possible that the Javanese they speak will more resemble the Javanese of the people around them. In addition, it should be noted that the realization of the teachings of Saminism in the conduct of each of its followers is not always the same so that the variant of Javanese they speak is also not 
completely uniform even though it still shows the same characteristics.

Samin people, who live in geographically dispersed places, still speak the same Javanese variant which is different from the Javanese of the people around them. Their Javanese variant has unified them in one speech community and gives them a group identity marker. This marker distinguishes the Samin from non-Samin people. The Javanese variant they speak reflects and constructs their identity.

Kabir (2013) said that identity is a process that is fluid and is shaped according to circumstances and opportunities. This statement also applies to the Samin people in relation to the Javanese variant that they speak as a marker of their identity. When speaking to outsiders, the Samin people generally speak their variant of Javanese. They do not feel the need to adapt to the language of their interlocutor and their identity can be recognized. On certain occasions, however, some Samin people adjust their language so that their speech no longer reflects their identity. Indeed, such an attitude does not necessarily mean that they are hiding their identity, but it could just be an attempt to make the conversation comfortable.

The relationship betweem ideology, language and identity in the case of the Samin people is linear or one way. Their ideology influences their language, and then, their language constructs their identity. If ideology is seen as a part of thought and identity is seen as a part of culture, what has happened in the Samin community is not in line with the findings of most researchers regarding the relationship between language, thought and culture. As Ahearn (2012:70) said, language, thought, and culture are all viewed as influencing one another in a flexible, mutually constitutive way. It seems that the inconsistency of relationships between language, thought, and culture in the Samin community with the general tendency is because the term language in this context refers to a variant of a language, not language in a general sense. Thus, language, thought and culture are mutually influencing remains an strong thesis. However, when the term language is used in a narrower sense, referring to language variants, the relationship between language, thought and culture might change from the general tendency, and be more deterministic.

\section{CONCLUSION}

As a part of Javanese society, the Samin people speak Javanese. In speaking they (i) tend to speak in Javanese at the ngoko level, (ii) use a special vocabulary, and (iii) show a different speaking attitude from Javanese speakers in general. These three characteristics of their language are influenced by the Saminism ideology they follow. Therefore, to understand the Javanese of the Samin people, an understanding of the Saminism ideology is needed. The misunderstanding of outsiders towards the Javanese of the Samin people is most likely due to people's lack of understanding of the ideology internalized by the speakers.

Theoretically, this study finds that the relationship between language, ideology and identity tends to be one-way. Ideology influences language, then language constructs and marks the identity of its speakers. It should be noted however, that what is meant by language in this context is a variant of a language, not language in the general sense. This finding needs to be confirmed by studies of ideological variants in other languages. Because, to date it is understood that at a more general level the relationship of language, thought and culture is mutually influencing. In addition, it should also be noted that the relationship of language, ideology and identity is complex and may vary from one case to another.

\section{ACKNOWLEDGEMENT}

This article's research was funded by the Faculty of Cultural Sciences, Universitas Gadjah Mada in 2013.

\section{REFERENCES}

Ahearn, L. M. (2012). Living Language: An Introduction to Linguistic Anthropology. West Sussex: WileyBlackwell.

Benda, Harry J. and Lance Castles (1969). The Samin Movement. Bijdragen tot de Taal-, Land-en Volkenkunde, 125, 207-240.

Brustad, Kristen (2017). Diglossia as Ideology. In Jacob Høigilt and Gunvor Mejdell (ed.), The Politics of Written Language in the Arab World: Writing Change. Leiden: Brill.

Chakraborty, Roshni (2018). Language and Identity in South Asia. Harvard International Review, 39(3), 14-17.

Chambers, J. K., Trudgill, P, \& Schilling-Estes, N. (Eds.) (2003). The Handbook of Language Variation and Change. Massachusetts: Blackwell Publishing.

Carlin, Eithne B., Isabelle Léglise, Bettina Migge and Paul B. Tjon Sie Fat (2015). Looking at Language, Identity, and Mobility in Suriname. In Carlin, Eithne B. et al. (Ed.), In and Out of Suriname: Language, Mobility and Identity. Leiden: Brill.

Dunmore, Stuart S. (2019). Language Revitalisation in Gaelic Scotland: Linguistic Practice and Ideology. 
Edinburgh: Edinburgh University Press.

Eckert, P. and Rickford, J. R. (Eds.) (2001). Style and Sociolinguistic Variation. New York: Cambridge University Press.

Edwards, J. (2009). Language and Identity: An Introduction . London: Cambridge University Press.

Errington J. (1982). Speech in the Royal Presence: Javanese Palace Language. Indonesia, 34, 89-101.

Fatmawati, Aristia (2017). Pelanggaran Prinsip Kerjasama dalam Tuturan Masyarakat Samin. Jalabahasa, 13(1), $1-13$.

Foley, W. A. (1997). Anthropological Linguistics. Massachusetts: Blackwell Publisher Inc.

Field, M. (2012). Kumeyaay Language Variation, Group Identity, and The Land. International Journal of American Linguistics, 78(4), 557-573.

Hansen, G. J. and Liu, J. (1997). Social Identity and Language: Theoretical and Methodological Issues. TESOL Quarterly, 31(3), 567-576.

Hill, Jane (2001). Languages on the Land. In J. E. Terrell (Ed.), Archaeology, Language and History: Essays on Culture and Ethnicity, pp. 257-82. Westport, Conn.: Bergin and Garvey.

Ige, B. (2010). Identity and language choice: 'We equals I'. Journal of Pragmatics, 42, 3047-3054.

Irvine J.T \& Gal S. (2000). Language Ideology and Linguistic Differentiation. In PV Kroskrity (Eds.). Regimes of Language: Ideologies, Polities, and Identities, pp. 35-84. Santa Fe: School of American Research Press.

Joseph, J.E. (2004). Language and Identity: National, Ethnic, Religious. Basingstoke: Houndmills.

Kabir, Nahid Afrose (2013). Young American Muslims: Dynamics of Identity. Edinburgh: Edinburgh University Press.

Lian. Chaoqun (2020). Language, Ideology and Sociopolitical Change in the Arabic-speaking World: A Study of the Discourse of Arabic Language Academies. Edinburgh: Edinburgh University Press.

Loeb. E. M. (1944). Javanese Word Formation, High and
Low. Journal of the American Oriental Society, 64(3), 113-126.

Mardikantoro (2012a). Pergeseran Bahasa Jawa pada Masyarakat Samin di Kabupaten Blora. Disertasi. Fakultas Ilmu Budaya, Universitas Gadjah Mada.

Mardikantoro (2012b). Pilihan Bahasa Masyarakat Samin dalam Ranah Keluarga. Humaniora, 24(3), 345-357.

Margaret Field (2012). Kumeyaay Language Variation, Group Identity, and The Land. International Journal of American Linguistics, 78(4), 557-573.

Poedjosoedarmo, Soepomo (1968). Javanese Speech Levels. Indonesia, 6, 54-81.

Poedjosoedarmo, Soepomo (1982). Wordlist of Javanese Non-Ngoko Vocabularies. Indonesia, 7, 165-190.

Schieffelin, B, B, Woolard, K. A., \& Kroskity P. V. (Eds.) (1998). Language Ideologies: Practice and Theory. New York: Oxford University Press.

Shiraishi, Takashi. (1990). Dangir's Testimony: Saminism Reconsidered. Indonesia, 50, 95-120.

Stets, J. E.and Burke, P. J. (2000). Identity Theory and Social Identity Theory. Social Psychology Quarterly, 63(3), 224-237.

Stryker, Sheldon (1980). Symbolic Interactionism: A Social Structural Version. Menlo Park, CA: Benjamin Cummings.

Suhandano (2015). Leksikon Samin sebagai Cermin Pandangan Dunia Penuturnya. Litera, 14(1), 99-109.

Tagliamonte, S. A. (2006). Key Topics of Sociolinguistics: Analysing Sociolinguistic Variation. New York: Cambridge University Press.

Watson, J. C. E. et al. (2005). The language of Jabal Rāzih: Arabic or Something Else? Proceedings of the Seminar for Arabian Studies, 36, 35-41.

Wierzbicka, Anna (1992). Semantics, Cognition and Culture. London: Oxford University Press.

Wierzbicka, Anna (1997). Understanding Culture Through Their Key Words. New York: Oxford University Press.

Woolard, K.A. and Schieffelin, B. B. (1994). Language Ideology. Annual Review of Anthropology, 23, 55-82. 